\title{
Development of QCM Biosensor with Specific Cow Milk Protein Antibody for Candidate Milk Adulteration Detection
}

\author{
Setyawan P. Sakti, ${ }^{1}$ Nur Chabibah,, ${ }^{1}$ Senja P. Ayu, ${ }^{2}$ \\ Masdiana C. Padaga, ${ }^{3}$ and Aulanni'am Aulanni' am ${ }^{4}$ \\ ${ }^{1}$ Department of Physics, Brawijaya University, Malang 65145, Indonesia \\ ${ }^{2}$ Department of Biology, Brawijaya University, Malang 65145, Indonesia \\ ${ }^{3}$ Faculty of Animal Husbandry, Brawijaya University, Malang 65145, Indonesia \\ ${ }^{4}$ Department of Chemistry, Brawijaya University, Malang 65145, Indonesia \\ Correspondence should be addressed to Setyawan P. Sakti; sakti@ub.ac.id
}

Received 31 August 2015; Revised 27 October 2015; Accepted 28 October 2015

Academic Editor: Chenzhong Li

Copyright (C) 2016 Setyawan P. Sakti et al. This is an open access article distributed under the Creative Commons Attribution License, which permits unrestricted use, distribution, and reproduction in any medium, provided the original work is properly cited.

\begin{abstract}
Adulteration of goat milk is usually done using cow's milk product. Cow milk is used as it is widely available and its price is cheaper compared to goat milk. This paper shows a development of candidate tools for milk adulteration using cow milk. A quartz crystal microbalance immunosensor was developed using commercial crystal resonator and polyclonal antibody specific to cow milk protein. A specific protein at $208 \mathrm{KDa}$ is found only in cow milk and does not exist in goat milk. The existence of this protein can be used as an indicator of cow milk content in a target solution. To detect the PSS $208 \mathrm{kDa}$ protein, antibody specific to the PSS 208 was developed. The purified antibody was immobilized on top of the sensor surface on a polystyrene layer. The fraction of the immobilized antibody on the sensor was found at $1.5 \%$ of the given antibody. Using a static reaction cell, the developed immunosensor could detect the specific cow milk protein in buffer solution. The detection limit is 1 ppm. A linear relationship between frequency change and specific protein of cow milk concentration is found from a concentration of $1 \mathrm{ppm}$ to $120 \mathrm{ppm}$.
\end{abstract}

\section{Introduction}

Milk is one of the dairy products, which is one of the most consumed products. Milk production and consumption in developing countries have been increasing significantly [1] . People consume milk, which is produced by animals such as cow, buffalo, goat, sheep, camel, donkey, horse, reindeer, and yak. Nutrition contents of milk have been known as a good source for human health [2]. Milk products from different animals have their own specific compositions [3,4]. Cow milk is one of the largest milk products in the world.

According to FAO, world goat milk production from 2009 to 2012 is only $2.4 \%$ of global milk production compared to 83\% for cow milk production [5]. In Southeast Asia, goat milk production is $6.2 \%$ whilst cow milk production is $87 \%$. These show that the availability of goat milk is far below the availability of cow milk. The low production of goat milk and its increasing demands lead to a significant price difference between goat milk and cow's milk. In Indonesia, the goat milk's price is four times higher than cow milk price. This condition makes many traders adulterating goat's milk with cow milk to gain more profit. In other countries, adulteration of sheep milk or goat milk with cow milk was also practiced $[6,7]$.

Physically, it is very difficult to distinguish between cow milk and goat milk. Differentiation is more difficult when both types of milk were mixed. Mixing practice can lead to a serious health problem to a person who has been allergic to cow milk or to those who practice a dietary treatment due to some health reason. In some countries, it is also compulsory to state the origin of the milk used to manufacture a product such as cheese to protect the consumer right [8].

Many methods have been developed to identify any milk adulteration in other milk products or to differentiate the milk products. Most of the methods were based on a laboratory intensive procedure such as ELISA, PCR, spectroscopy, 
chromatography, and HPLC [6-13]. Those methods were successfully developed to identify milk adulteration. Unfortunately, the methods were only suitable for big industries or government institutions, which normally have enough resources. A simple system, with simple analytical instrument, is needed to detect goat milk adulteration, which can be used in domestic milk farming. For a qualitative detection of cow milk, one can develop using Western dot blot technique. Simple low cost instrumentation to detect adulteration involving synthetic milk has been reported [14], but not adulteration using real milk from different animal. One good candidate to detect milk adulteration is by using quartz crystal microbalance (QCM). As shown in many works, the QCM sensor has been proved to be a good immunosensor [15-20]. Commercial quartz crystal resonator with polystyrene coating has been used successfully and developed as a basis for QCM Immunosensor [21-25]. In this work, we present a candidate tool to identify the existence of cow milk in solution by utilizing a quartz crystal microbalance coated with polystyrene. Further development of the QCM sensor, for example, can be used to detect the presence of cow milk in goat milk. The system was developed based on the protein profile difference between cow milk and goat milk. It has been found that a specific protein with a molecular weight of $208 \mathrm{kDa}$, in this work we call as a PSS 208 , exists only in cow milk. PSS 208 does not exist in the goat milk. Therefore, detecting the presence of the PSS 208 protein can indicate the existence of cow milk in a target solution.

\section{Experimental Section}

2.1. Material and Equipment. For developing the QCM biosensor, commercially crystal resonator with silver electrode having resonance frequency of $10 \mathrm{MHz}$ was purchased from Great Micro Electronic, Surabaya, Indonesia. Quartz crystal resonator disc has $8.7 \mathrm{~mm}$ diameter with round silver electrode of $5 \mathrm{~mm}$. The quartz crystal has a standard dimension of HC-49/U. Polystyrene coating layer was made from polystyrene well plate for ELISA (Nunc MaxiSorp) which was solved using reagent grade chloroform. The chloroform was purchased from Sigma Aldrich.

The equipment used in the measurement was an oscillator circuit for the QCM sensor developed based on the circuit as described in the work of Eichelbaum et al. [26], a frequency counter with resolution of $1 \mathrm{~Hz}$, personal computer for data recording, and micropipette from Eppendorf. The frequency counter has been calibrated to a standard rubidium frequency source. A general purpose spin coater VTC-100 from MTI Corporation was used for the sensor coating. Detection of the PSS 208 protein was done using a static reaction cell. Figure 1 shows the top view of the reaction cell with installed sensor attached to the oscillator system. Similar system has been used in other applications successfully [24].

Protein specific and antibody were extracted and purified using standard equipment at Bioscience Laboratory, Brawijaya University. PBS-Tween-PMSF, Tris-HCL buffer, Biuret reagent, and other biochemical materials for the purification were purchased from Sigma Aldrich. Cow and goat milk was purchased from local farmers in Malang, Indonesia.

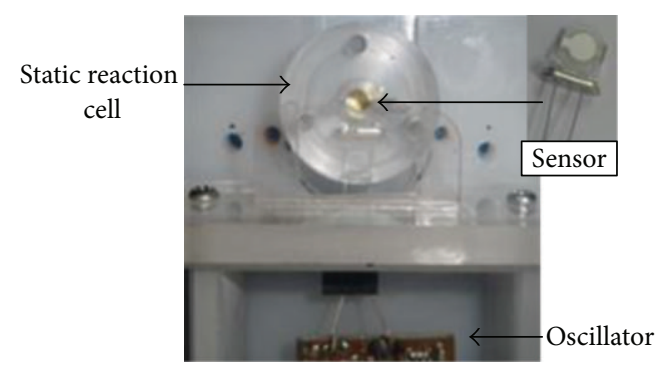

FIGURE 1: Static reaction cell and QCM sensor.

Antibody concentration used was ranging from $200 \mathrm{ppm}$ to $2000 \mathrm{ppm}$. Each concentration was prepared from a single stock antibody with concentration of $2000 \mathrm{ppm}$. The concentration of specific cow milk protein (PSS 208) used in this experiment was $1 \mathrm{ppm}$ to $120 \mathrm{ppm}$. The concentration was made from single source of $120 \mathrm{ppm}$ concentration.

\subsection{Specific Protein Purification and Antibody Preparation.} Specific protein used in this work was extracted using electrophoresis. The protein was confirmed using SDS-PAGE method [27]. An SDS PAGE with gel separation of 15\% and gel stacking of 3\% was used. The electrophoresis was conducted by using a constant current of $200 \mathrm{~mA}$. Protein distribution was identified using Coomassie Brilliant Blue (CBBR 250) color. A specific protein with a specific molecular weight of cow milk was selected, where no protein in the goat milk with a same molecular weight was present. Protein purification of the selected protein was done by using electroelution.

Antibody for specific cow milk protein was produced by using rabbit which was treated in accordance with the animal ethics regulation set by the Brawijaya University Animal Use Ethics. New Zealand rabbit was immunized using specific protein solution. Antibody to the specific protein was collected from the blood serum of the rabbit after 8 weeks of incubation. The specificity of the antibody against specific cow milk protein was tested using Western blotting method.

\subsection{QCM Biosensor Development and Measurement. Direct} use of the general purpose crystal resonator with silver electrode is inappropriate for biomolecule immobilization. The silver electrode can react unexpectedly with buffer solution which can affect the resonance frequency of the QCM. Therefore, the surface of the sensor was coated with a polystyrene. Polystyrene coating was done by spin coating technique at a rotation speed of $3000 \mathrm{rpm}$ by rapid dropping of polystyrene solution in amount of $50 \mu \mathrm{L}$. The concentration of the polystyrene was $3 \%$ in chloroform. Preliminary experiment has been conducted, and we found that polystyrene coating done with spin coating using polystyrene in chloroform up to $8 \%$ does not affect the mechanical and electrical performance of the sensor. Observation using an optical microscope was done to ensure that the entire surface of the sensor is covered by the polystyrene. The coating of both sides of the quartz crystal resonator is to protect the metal electrode from being oxidized and from being in contact with 
TABLE 1: Protein profile matrix of cow milk (CM), goat milk (GM), cow colostrum (CC), and goat colostrum (GC).

\begin{tabular}{|c|c|c|c|c|c|c|c|c|c|c|c|c|c|}
\hline \multirow{2}{*}{ Sample source } & \multicolumn{13}{|c|}{ Molecular weight $(\mathrm{kDa})$} \\
\hline & 9.5 & 12 & 13 & 16 & 19 & 23 & 51 & 80 & 95 & 106 & 113 & 119 & 208 \\
\hline $\mathrm{CM}$ & $\sqrt{ }$ & $\sqrt{ }$ & $\sqrt{ }$ & $\sqrt{ }$ & & & $\sqrt{ }$ & $\sqrt{ }$ & & & & $\sqrt{ }$ & $\sqrt{ }$ \\
\hline GM & $\sqrt{ }$ & & & & $\sqrt{ }$ & $\sqrt{ }$ & & & & $\sqrt{ }$ & & & \\
\hline CC & $\sqrt{ }$ & $\sqrt{ }$ & & $\sqrt{ }$ & & & $\sqrt{ }$ & $\sqrt{ }$ & $\sqrt{ }$ & & $\sqrt{ }$ & & $\sqrt{ }$ \\
\hline GC & $\sqrt{ }$ & & & & $\sqrt{ }$ & & $\sqrt{ }$ & $\sqrt{ }$ & & & $\sqrt{ }$ & & \\
\hline
\end{tabular}

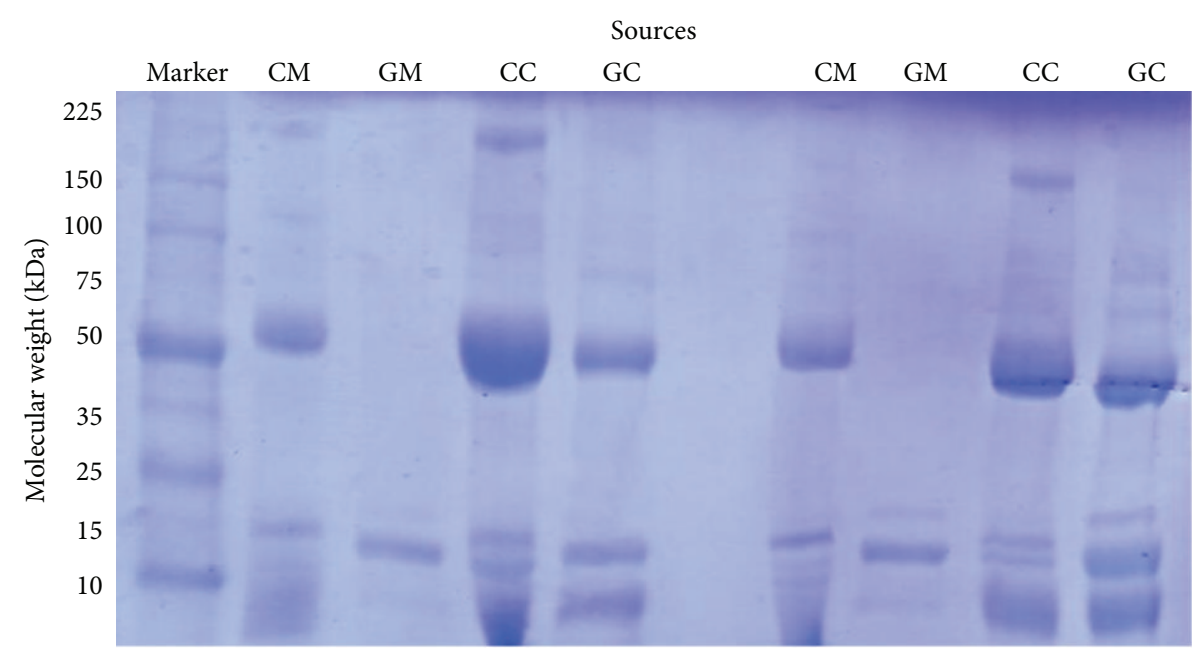

FIGURE 2: Electrophoresis gel profile of cow milk (CM), goat milk (GM), cow colostrum (CC), and goat colostrum (GC).

buffer solution. Electrode oxidation leads to an unexpected resonance frequency change of the sensor [28].

Determination of optimum antibody concentration to be immobilized on top of the QCM sensor was done as follows. After the sensor was installed in the static reaction cell, $70 \mu \mathrm{L}$ Tris-HCl buffer was added on top of the sensor surface. After a steady resonance frequency was reached, which took around 30 minutes, $30 \mu \mathrm{L}$ of the antibody solution was injected into the buffer solution to the sensor surface. The frequency change was recorded until a new steady resonance frequency was achieved. The difference between both steady resonance frequencies was taken as a frequency change caused by antibody immobilization.

Antibody immobilization for QCM biosensor preparation to detect cow milk concentration was done by putting $30 \mu \mathrm{L}$ antibody solution at optimum concentration on top of the sensor surface. Immobilization was done overnight by keeping the sensor in a storage with adequate humidity to avoid antibody solution from drying. After immobilization, the sensor surface was washed using Tris-HCl buffer followed by BSA blocking. BSA blocking was done by adding $30 \mu \mathrm{L}$ BSA solution (1\%) on the immobilized sensor surface for 30 minutes and followed by washing procedure using PBS. Detection of protein specific cow milk was done by adding $30 \mu \mathrm{L}$ protein specific cow milk solution on top of a sensor surface. Prior to the solution injection, the sensor reaction cell was added with $70 \mu \mathrm{L}$ Tris-HCl buffer. After steady resonance frequency was reached, $30 \mu \mathrm{L}$ protein specific of cow milk solution with different concentration was injected into the buffer solution. The injection was followed by a resonance frequency change of the sensor until reaching a new steadystate resonance frequency. The difference frequency between both steady-state resonance frequencies was recorded as a frequency change caused by the reaction between protein specific and immobilized antibody. The reaction between the protein and sensor occurred in less than 30 minutes.

\section{Results and Discussion}

3.1. Specific Protein of Cow Milk Selection and Antibody Production. Key factor for the immunosensor development was a selection of specific antibody against target biomolecule to be detected. A potential candidate antibody to be used as a specific bioselective layer for the QCM sensor was investigated using protein. As we developed a candidate biosensor to detect cow milk adulteration in goat milk, protein profiling was done and aimed to select a specific protein that only exists in cow's milk.

Following the protein isolation and purification, an electroelution procedure was done to select a specific protein of the cow milk. Figure 2 shows an electrophoresis gel image of the goat milk, cow milk, goat colostrum, and cow colostrum. From Figure 2, one can see a protein profile of goat and cow's milk. Table 1 shows a summary of the protein profile taken at the central band of the protein profile of the electrophoresis gel.

Different protein profile between cow milk, cow colostrum, goat milk, and goat colostrum can be seen in Table 1. Candidate proteins which can be used as a marker for the existence of cow milk were protein with molecular weight of 


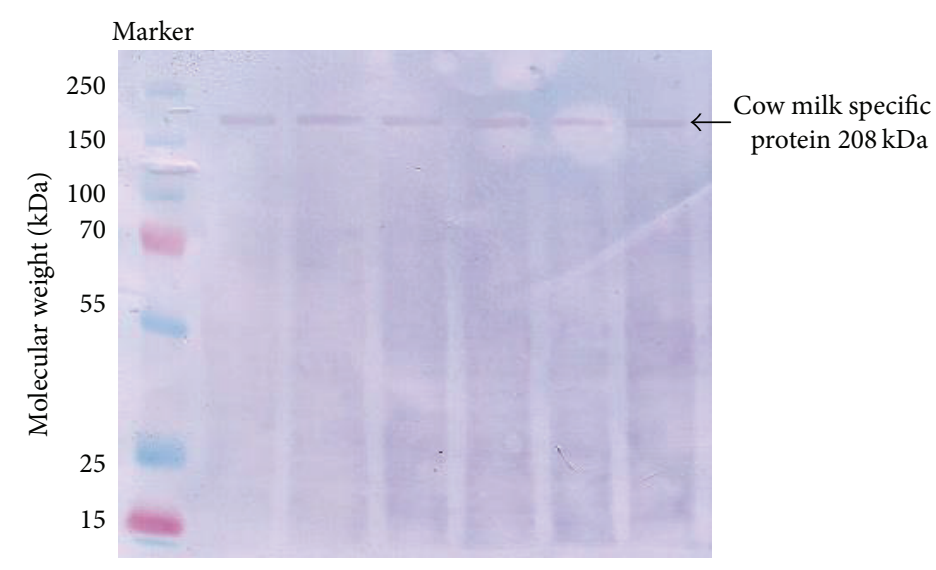

FIGURE 3: Western blotting test result of the developed polyclonal antibody.

12,16 , and $208 \mathrm{kDa}$. From those many candidate proteins, we select the $208 \mathrm{kDa}$ protein (PSS 208) as a candidate to detect the existence of cow milk. The selection was based on an assumption that a bigger molecular weight should result in a heavier mass per surface area that should be preferable to be detected using QCM sensor. Protein with molecular weight of $208 \mathrm{kDa}$ was known as K-casein protein.

Antibody to specific cow milk specific protein (anti-PSS 208) was produced by introducing purified specific cow milk protein PSS 208 to rabbit (conforming to the rule set by the Brawijaya University Animal Care and Use Committee). The polyclonal antibody was then extracted from the rabbit serum after nine-week incubation. Specificity of the polyclonal antibody was tested again cow milk using Western blotting. Figure 3 shows that the developed antibody can specifically only bind with the cow milk specific protein $208 \mathrm{kDa}$. Strong marker line was seen at molecular weight of $208 \mathrm{kDa}$. No other line was observed on the gel plate indicating that the polyclonal antibody in use was specifically reacted with target protein at $208 \mathrm{kDa}$.

\subsection{Response of the QCM Biosensor to Cow Milk Specific} Protein. The development of the candidate QCM biosensor to detect the presence of cow milk within milk adulteration was done by immobilizing the polyclonal antibody specific (anti-PSS 208) to the cow milk protein $208 \mathrm{kDa}$. Optimum concentration for the antibody immobilization was obtained by measuring frequency change of the $10 \mathrm{MHz}$ QCM caused by different concentration of anti-PSS 208 to be immobilized. Figure 4 shows that increasing anti-PSS 208 concentrations to be immobilized results in increasing frequency change of the sensor.

The increase frequency change, which reached its maximum at $260 \mathrm{~Hz}$, correlates with 1000 ppm anti-PSS 208. Increasing the antibody concentration was not followed by increasing the frequency change of the sensor. This indicates that the maximum concentration of the immobilized antiPSS 208 was $1000 \mathrm{ppm}$. This information was important to note that giving higher anti-PSS 208 concentration to be immobilized was useless and only wasting the antibody.

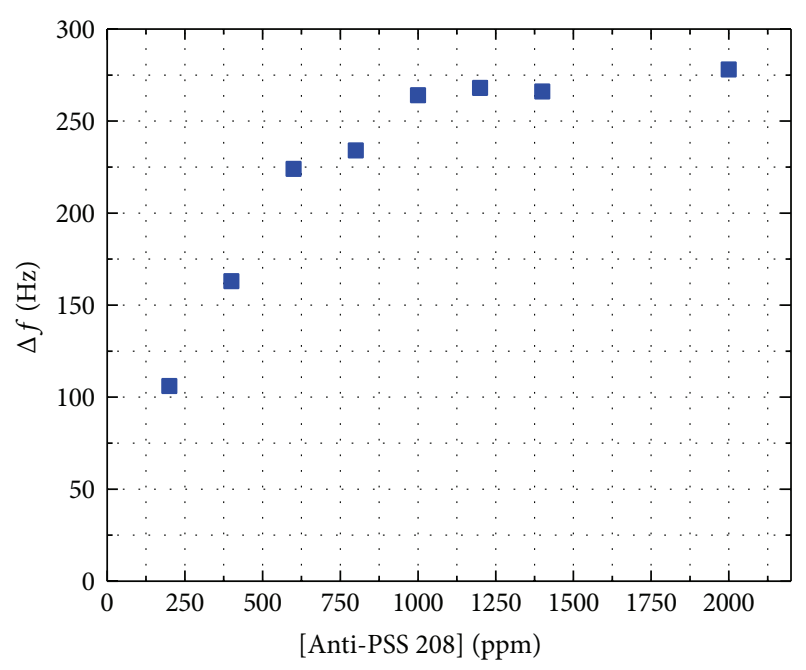

FigURE 4: Frequency change of the $10 \mathrm{MHz}$ QCM sensor caused by anti-PSS 208 immobilization from different concentration.

Based on the Sauerbrey equation, the deposited mass on the sensor surface can be calculated based on the frequency change of the QCM sensor. Figure 5 shows the percentage of the immobilized antibody on the sensor surfaces against given different antibody concentrations. The percentage of the immobilized mass was calculated based on the Sauerbrey equation [29] and total mass of the antibody based on the given antibody concentration in the solution.

Higher concentration resulted in a lower percentage of immobilized antibody. At $1000 \mathrm{ppm}$, only $1.5 \%$ of the antibody in the solution given on top of the sensor surface was immobilized on the sensor surface. This result suggested that the binding rate of the antibody on top of the sensor surface through physical adsorption was affected by concentration of the antibody solution.

The observation over the ability of the QCM biosensor to detect the existence of PSS 208 cow milk specific protein was conducted by measuring the frequency change of the sensor with antibody specific layer. Frequency change was recorded during an addition of specific protein solution 


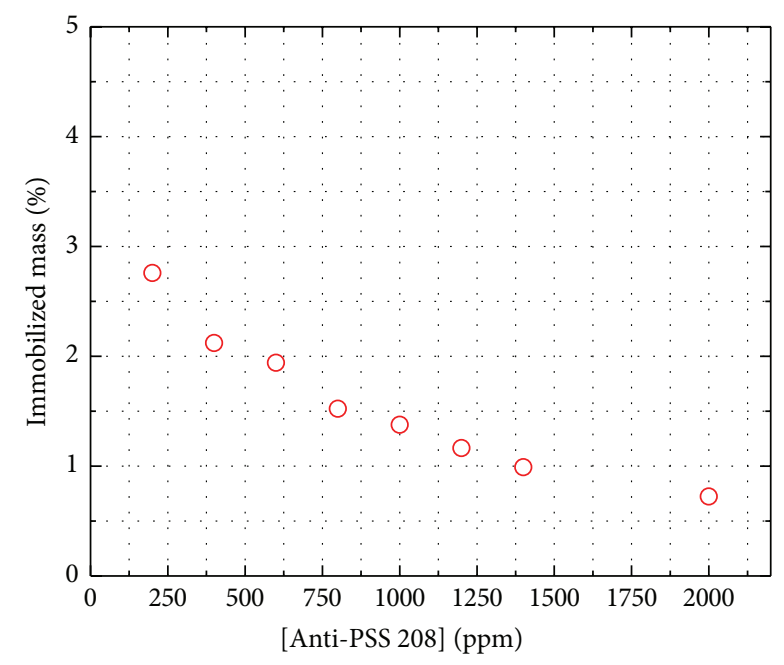

FIGURE 5: Percentage of immobilized anti-PSS 208 at different solution concentration.

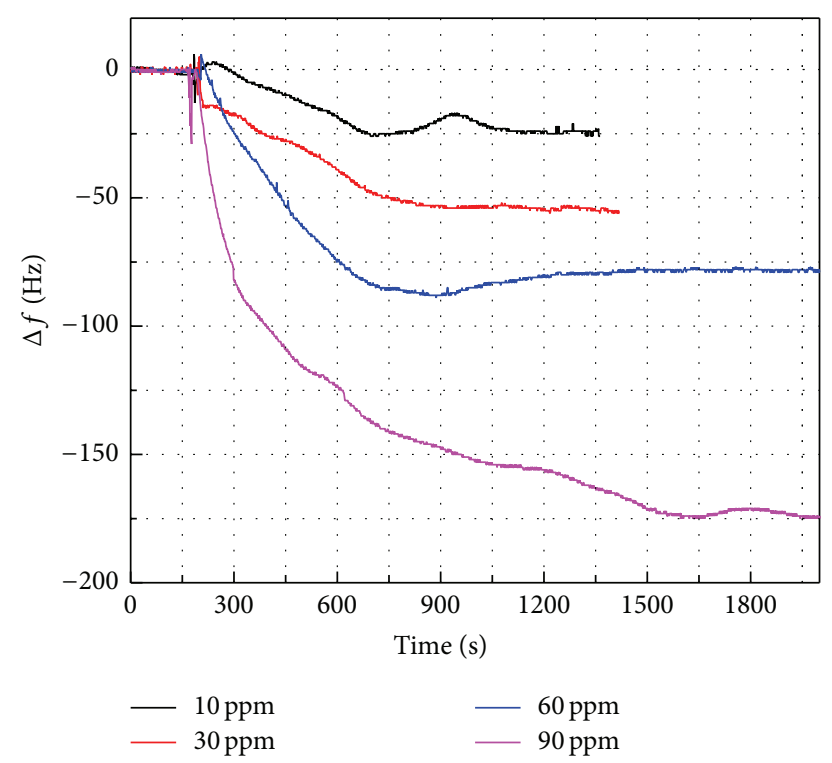

FIGURE 6: Frequency change of the developed QCM biosensor caused by PSS 208 solution.

on top of the sensor surface. Different concentrations of PSS 208 in a Tris-HCL buffer were used. Figure 6 shows a typical sensor signal when the target solution (PSS 208) was dropped on the buffer solution on top of the sensor surface. At a time, when the sample solution was being dropped, a disturbing signal occurred, which was then followed by decreasing resonance frequency caused by the reaction of the PSS 208 with the immobilized PSS 208 antibody. Higher PSS 208 concentration required longer steady-state resonance frequency. At longest time, the reaction took 30 minutes.

Figure 7 shows the frequency change of the sensor to reach its new steady states 20 to 30 minutes after injection of the PSS 208 solution. As is expected, frequency change of the sensor increased according to the increasing concentration of the specific protein solution. From a given concentration of

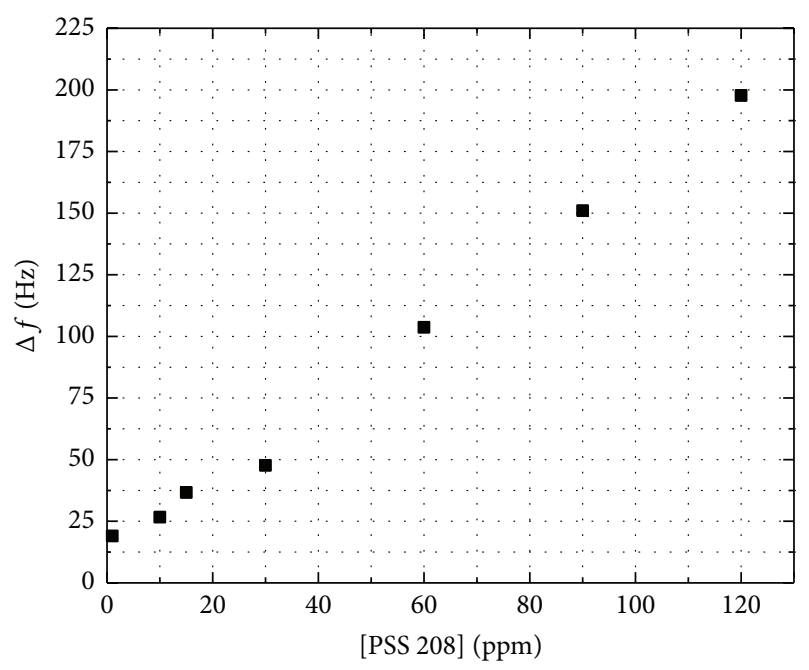

FIGURE 7: Frequency change of the QCM sensor at given PSS 208 concentration in buffer solution.

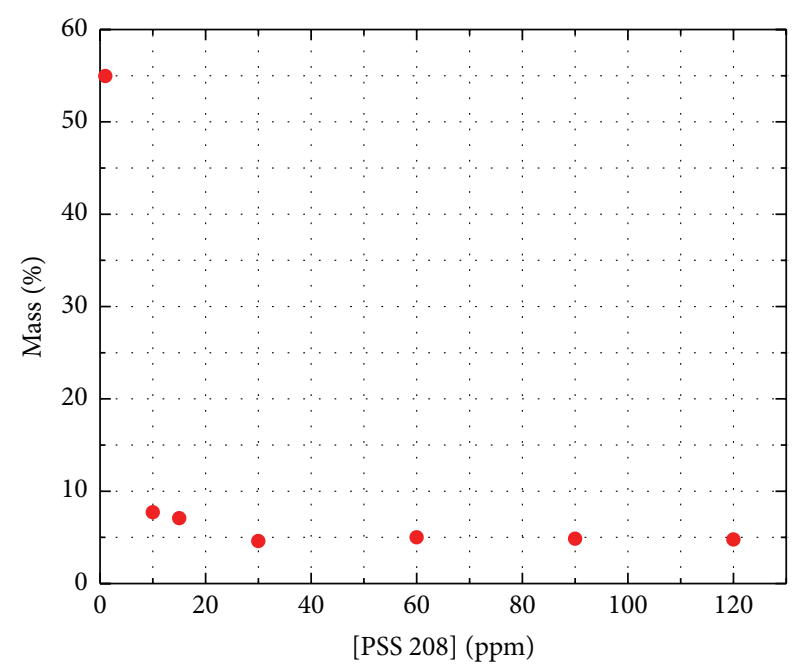

FIGURE 8: Percentage of the given protein (PSS 208) that reacts with the immobilized antibody on top of the sensor.

$1 \mathrm{ppm}$ to $120 \mathrm{ppm}$, the frequency change of the QCM sensor was increasing linearly with the increasing concentration of the PSS 208. At concentration less than $1 \mathrm{ppm}$, the sensor did not show any frequency change.

Those limits of detection were adequate to identify any milk adulteration using cow milk. With those low limits of detection, no economic advantages can be gained. It does not give any economic benefits to add cow's milk with a concentration of less than $1 \%$ to the milk adulterator.

Using the Sauerbrey equation, by assuming that the protein behaves as a rigid material, we can convert the frequency change to mass of the protein that reacts with the sensor. By dividing the mass with a calculated given mass, we got the percentage of the protein in the solution which reacted to the immobilized antibody on top of the sensor surface. Figure 8 shows the percentage of the reacted protein against protein concentration in the buffer solution. 
At concentration lower than $20 \mathrm{ppm}$, the fraction of the given PSS 208 in the solution was slightly higher compared to those of higher concentrations. At higher concentrations, ranging from $20 \mathrm{ppm}$ to $120 \mathrm{ppm}$, the percentage of the protein reacted with the sensor was about 5 percent. This means that only $5 \%$ of the target PSS 208 molecule reacted with the immobilized antibody on the sensor surface. Assuming that the immobilized antibody was limited by the sensor surface area, it is expected that at a higher concentration the percentage of the target molecule (PSS 208) to the immobilized antibody will decrease. It can be explained that as the protein was suspended in the solution, only part of the protein, which touched the sensor surface, will react with the immobilized antibody. In addition the number of the immobilized antibodies is lower than the given PSS 208 protein in the solution.

\section{Conclusions}

We have shown that a QCM immunosensor can be used as a candidate method to detect milk adulteration using cow milk. The developed polyclonal antibody can be produced after protein profiling of the milk. The protein profiling was done by selecting a specific protein of the cow milk, which does not exist in the target milk being falsified, which, in our case, was goat milk. Optimum concentration of the polyclonal antibody for specific cow milk protein (PSS 208) was found at a concentration of $1000 \mathrm{ppm}$. Fraction of the antibody being immobilized on top of the QCM surface with polystyrene coating was just around $1.5 \%$. In the static cell reaction, only about $5 \%$ of the given PSS 208 was reacting with the immobilized antibody. The developed QCM immunosensor for detecting cow milk existence has a detection limit of $1 \mathrm{ppm}$. These limits of detection were adequate to be used as a candidate for goat milk adulteration using cow milk detection apparatus.

\section{Conflict of Interests}

The authors declare no conflict of interests.

\section{Acknowledgment}

This work was supported by a research grant funded by Directorate General of Higher Education of the Republic of Indonesia.

\section{References}

[1] S. Gerosa, J. Skoet, and ESA Working, "Milk availability trends in production and demand and medium-term outlook," ESA Working Paper 12-01, FAO, 2012.

[2] P. C. Pereira, "Milk nutritional composition and its role in human health," Nutrition, vol. 30, no. 6, pp. 619-627, 2014.

[3] J. M. Jandal, "Comparative aspects of goat and sheep milk," Small Ruminant Research, vol. 22, no. 2, pp. 177-185, 1996.

[4] Y. W. Park, M. Juárez, M. Ramos, and G. F. W. Haenlein, "Physico-chemical characteristics of goat and sheep milk," Small Ruminant Research, vol. 68, no. 1-2, pp. 88-113, 2007.
[5] FAO, "Food and Agriculture Organization of the United Nations: Statistics Division,” 2015, http://faostat3.fao.org/.

[6] H. Colak, A. Aydin, B. Nazli, and O. Ergun, "Detection of presence of cow's milk in sheep's cheeses by immunochromatography," Food Control, vol. 17, no. 11, pp. 905-908, 2006.

[7] H. Song, H. Xue, and Y. Han, "Detection of cow's milk in Shaanxi goat's milk with an ELISA assay," Food Control, vol. 22, no. 6, pp. 883-887, 2011.

[8] I. Mafra, Á. Roxo, I. M. P. L. V. O. Ferreira, and M. B. P. P. Oliveira, "A duplex polymerase chain reaction for the quantitative detection of cows' milk in goats' milk cheese," International Dairy Journal, vol. 17, no. 9, pp. 1132-1138, 2007.

[9] G. Cartoni, F. Coccioli, R. Jasionowska, and M. Masci, "Determination of cows' milk in goats' milk and cheese by capillary electrophoresis of the whey protein fractions," Journal of Chromatography A, vol. 846, no. 1-2, pp. 135-141, 1999.

[10] I. González-Martín, J. M. Hernández-Hierro, R. MorónSancho, J. Salvador-Esteban, A. Vivar-Quintana, and I. Revilla, "Determination of the percentage of milk (cow's, ewe's and goat's) in cheeses with different ripening times using near infrared spectroscopy technology and a remote reflectance fibre-optic probe," Analytica Chimica Acta, vol. 604, no. 2, pp. 191-196, 2007.

[11] H. K. Mayer, D. Heidler, and C. Rockenbauer, "Determination of the percentages of cows', ewes' and goats' milk in cheese by isoelectric focusing and cation-exchange HPLC of $\gamma$ - and para$\kappa$-caseins," International Dairy Journal, vol. 7, no. 10, pp. 619628, 1997.

[12] L. A. Dias, A. M. Peres, A. C. A. Veloso, F. S. Reis, M. VilasBoas, and A. A. S. C. Machado, "An electronic tongue taste evaluation: identification of goat milk adulteration with bovine milk," Sensors and Actuators B: Chemical, vol. 136, no. 1, pp. 209217, 2009.

[13] M. Ferrand-Calmels, I. Palhière, M. Brochard et al., "Prediction of fatty acid profiles in cow, ewe, and goat milk by mid-infrared spectrometry," Journal of Dairy Science, vol. 97, no. 1, pp. 17-35, 2014.

[14] S. Das, M. Sivaramakrishna, K. Biswas, and B. Goswami, "A low cost instrumentation system to analyze different types of milk adulteration," ISA Transactions, vol. 56, pp. 268-275, 2015.

[15] M. Michalzik, R. Wilke, and S. Büttgenbach, "Miniaturized QCM-based flow system for immunosensor application in liquid," Sensors and Actuators B: Chemical, vol. 111-112, pp. 410415, 2005.

[16] D. Li, J. Wang, R. Wang et al., "A nanobeads amplified QCM immunosensor for the detection of avian influenza virus $\mathrm{H} 5 \mathrm{N1}$," Biosensors and Bioelectronics, vol. 26, no. 10, pp. 4146-4154, 2011.

[17] M. E. Escuderos, S. Sánchez, and A. Jiménez, "Virgin olive oil sensory evaluation by an artificial olfactory system, based on Quartz Crystal Microbalance (QCM) sensors," Sensors and Actuators B: Chemical, vol. 147, no. 1, pp. 159-164, 2010.

[18] M. K. Mustafa, A. Nabok, D. Parkinson, I. E. Tothill, F. Salam, and A. Tsargorodskaya, "Detection of $\beta$-amyloid peptide (1-16) and amyloid precursor protein (APP770) using spectroscopic ellipsometry and QCM techniques: a step forward towards Alzheimers disease diagnostics," Biosensors and Bioelectronics, vol. 26, no. 4, pp. 1332-1336, 2010.

[19] I. Mannelli, M. Minunni, S. Tombelli, R. Wang, M. M. Spiriti, and M. Mascini, "Direct immobilisation of DNA probes for the development of affinity biosensors," Bioelectrochemistry, vol. 66, no. 1-2, pp. 129-138, 2005. 
[20] N. Kim, S.-H. Son, C.-T. Kim, Y.-J. Cho, C.-J. Kim, and W. Y. Kim, "Direct-binding quartz crystal microbalance immunosensor to detect carp metallothionein," Sensors and Actuators B: Chemical, vol. 157, no. 2, pp. 627-634, 2011.

[21] M. Z. Atashbar, B. Bejcek, A. Vijh, and S. Singamaneni, "QCM biosensor with ultra thin polymer film," Sensors and Actuators B: Chemical, vol. 107, no. 2, pp. 945-951, 2005.

[22] M. Michalzik, J. Wendler, J. Rabe, S. Büttgenbach, and U. Bilitewski, "Development and application of a miniaturised quartz crystal microbalance (QCM) as immunosensor for bone morphogenetic protein-2," Sensors and Actuators B: Chemical, vol. 105, no. 2, pp. 508-515, 2005.

[23] Z. Pei, H. Anderson, T. Aastrup, and O. Ramström, "Study of real-time lectin-carbohydrate interactions on the surface of a quartz crystal microbalance," Biosensors and Bioelectronics, vol. 21, no. 1, pp. 60-66, 2005.

[24] S. P. Sakti, F. Wahyuni, U. P. Juswono, and Aulanni'am, “Development of QCM immunosensor with small sample solution for detection of MMP-3 antibody," Sensors and Transducers, vol. 149, no. 2, pp. 143-148, 2013.

[25] M. S. Lord, C. Modin, M. Foss et al., "Monitoring cell adhesion on tantalum and oxidised polystyrene using a quartz crystal microbalance with dissipation," Biomaterials, vol. 27, no. 26, pp. 4529-4537, 2006.

[26] F. Eichelbaum, R. Borngräber, R. Lucklum, P. Hauptmann, and S. Rösler, "Oszillatoren für Quartz-Crystal-MicrobalanceSensoren in Flüssigkeiten," Technisches Messen, vol. 65, no. 12, pp. 434-444, 1998.

[27] U. K. Laemmli, "Cleavage of structural proteins during the assembly of the head of bacteriophage T4," Nature, vol. 227, no. 5259, pp. 680-685, 1970.

[28] S. P. Sakti, S. Rösler, R. Lucklum, P. Hauptmann, F. Bühling, and S. Ansorge, "Thick polystyrene-coated quartz crystal microbalance as a basis of a cost effective immunosensor," Sensors and Actuators A: Physical, vol. 76, no. 1-3, pp. 98-102, 1999.

[29] R. Fogel, P. Mashazi, T. Nyokong, and J. Limson, "Critical assessment of the Quartz Crystal Microbalance with Dissipation as an analytical tool for biosensor development and fundamental studies: metallophthalocyanine-glucose oxidase biocomposite sensors," Biosensors and Bioelectronics, vol. 23, no. 1, pp. 95-101, 2007. 


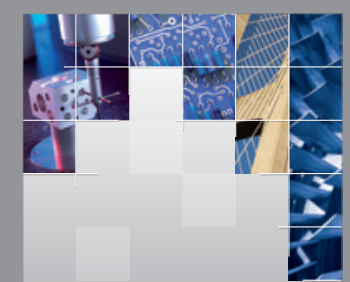

\section{Enfincering}
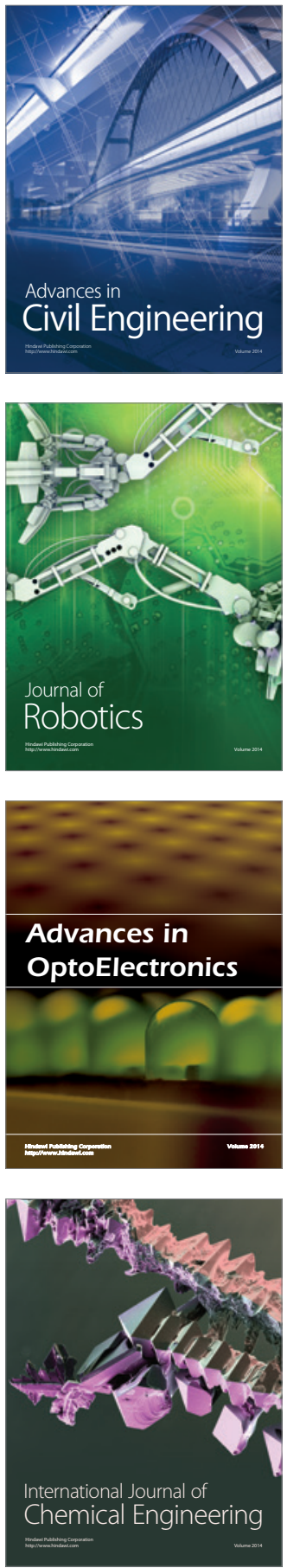

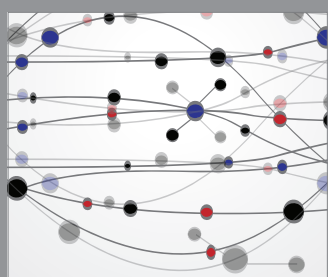

The Scientific World Journal

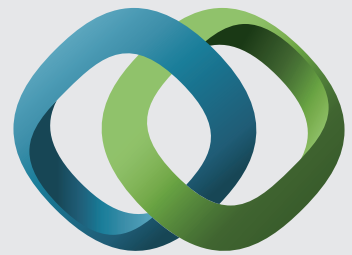

\section{Hindawi}

Submit your manuscripts at

http://www.hindawi.com
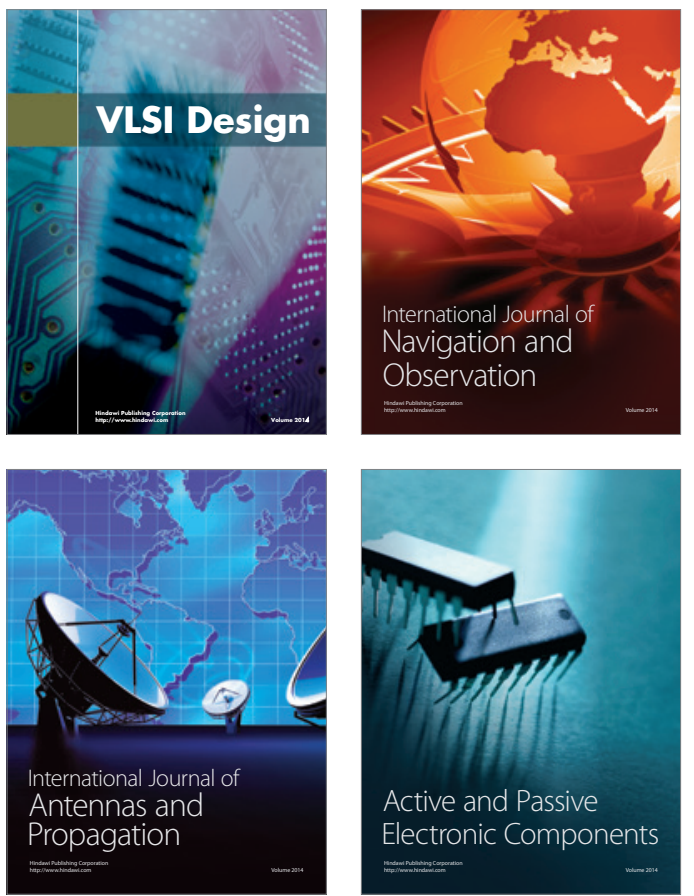
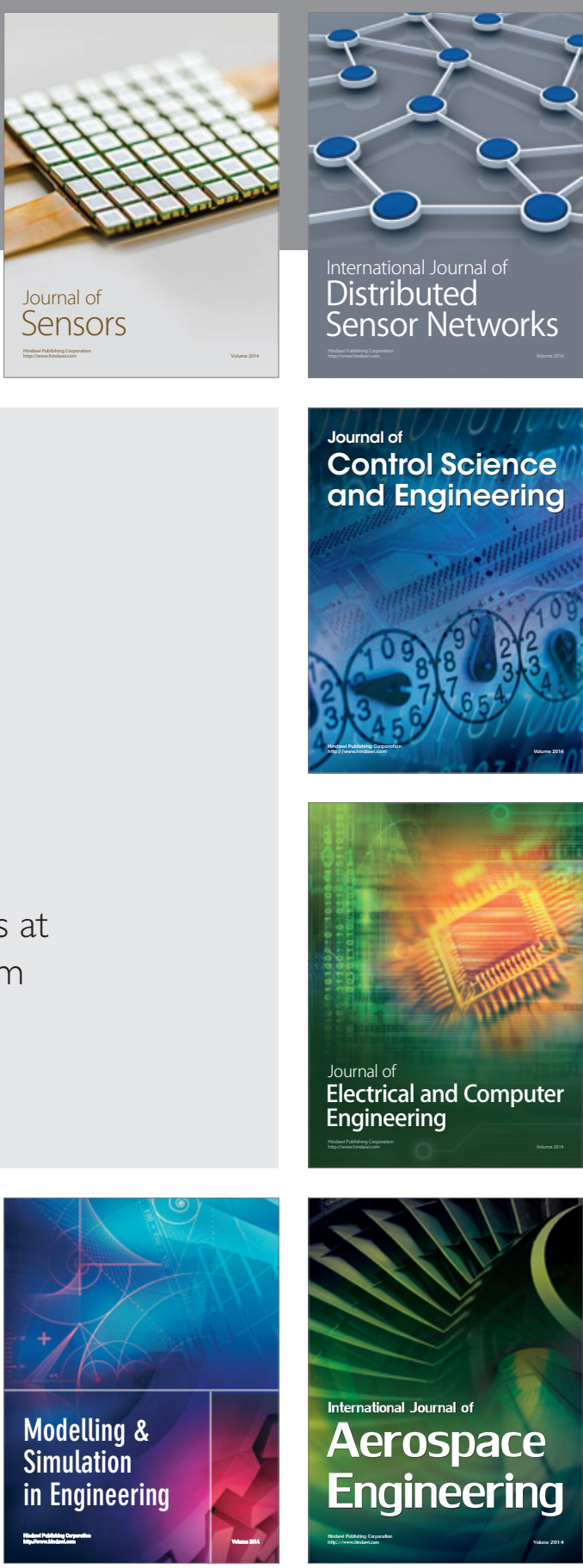

International Journal of

Distributed

Sensor Networks

Journal of

Control Science

and Engineering
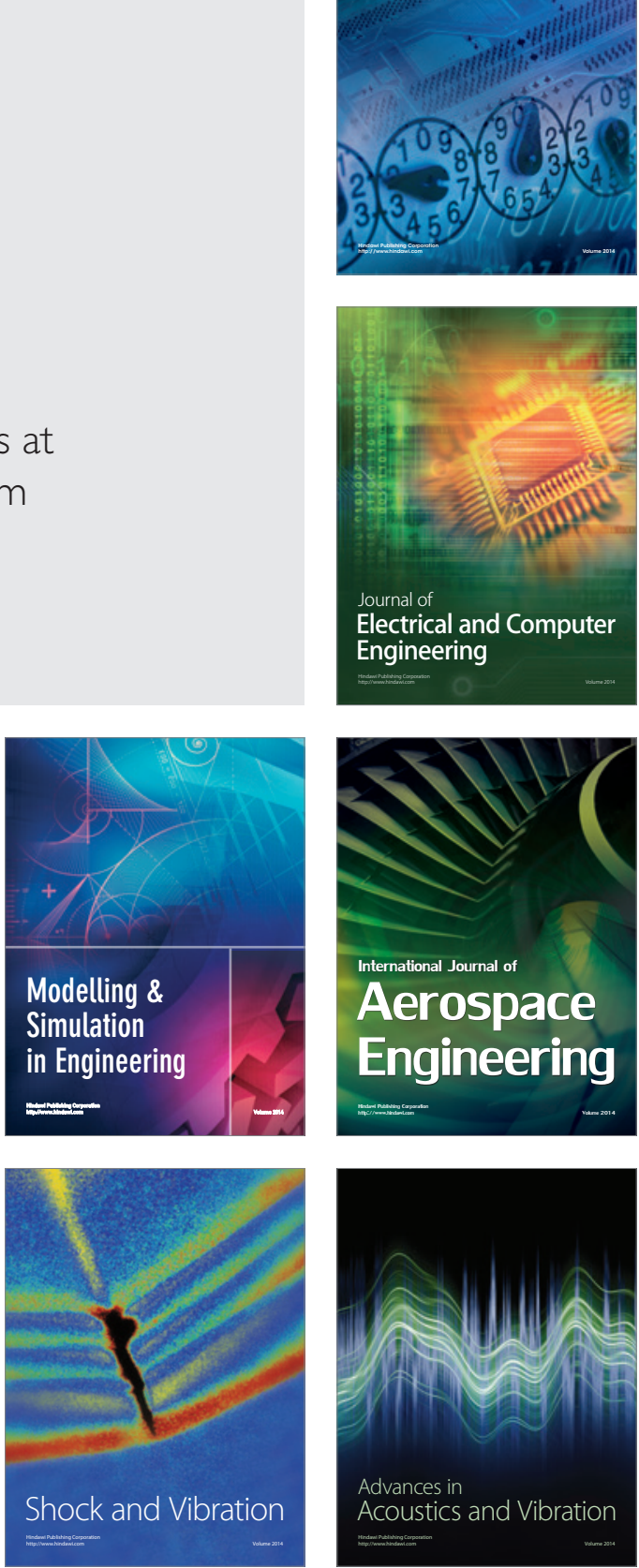